\title{
Nuclear Power Risk Perception in Serbia: Fear of Exposure to Radiation vs. Social Benefits
}

\author{
Vladimir M. Cvetković ${ }^{1, *(\mathbb{D})}$, Adem Öcal ${ }^{2}\left(\mathbb{D}\right.$, Yuliya Lyamzina ${ }^{3} \mathbb{D}$, Eric K. Noji ${ }^{4}$, Neda Nikolić ${ }^{5}$ \\ and Goran Milošević ${ }^{6}$ \\ 1 Faculty of Security Studies, University of Belgrade, 11040 Belgrade, Serbia \\ 2 Independent Researcher, Ankara 06500, Turkey; ocadem@gmail.com \\ 3 Louis Pasteur Center for Medical Research, Kyoto 606-8225, Japan; lyamzina@yahoo.com \\ 4 College of Medicine, King Saud University Hospitals, Riyadh 11451, Saudi Arabia; nojie@alumni.stanford.edu \\ 5 Faculty of Tehnical Science in Čačak, University of Kragujevac, 32000 Čačak, Serbia; neda.nikolic@ftn.kg.ac.rs \\ 6 Faculty of Law, University of Novi Sad, Trg Dositeja Obradovića 1, 21000 Novi Sad, Serbia; \\ g.milosevic@pf.uns.ac.rs \\ * Correspondence: vmc@fb.bg.ac.rs
}

Citation: Cvetković, V.M.; Öcal, A.; Lyamzina, Y.; Noji, E.K.; Nikolić, N.; Milošević, G. Nuclear Power Risk Perception in Serbia: Fear of Exposure to Radiation vs. Social Benefits. Energies 2021, 14, 2464. https://doi.org/10.3390/en14092464

Academic Editor: Guglielmo Lomonaco

Received: 24 March 2021

Accepted: 21 April 2021

Published: 26 April 2021

Publisher's Note: MDPI stays neutral with regard to jurisdictional claims in published maps and institutional affiliations.

Copyright: (C) 2021 by the authors. Licensee MDPI, Basel, Switzerland. This article is an open access article distributed under the terms and conditions of the Creative Commons Attribution (CC BY) license (https:/ / creativecommons.org/licenses/by/ $4.0 /)$.

\begin{abstract}
Nuclear power remains one of the most accessible choices in addressing environmental and social concerns due to the continuously increasing energy needs around the world. While it remains an excellent source of energy due to its low price and low level of emissions, potential accidents remain a serious problem. An example of such is the most recent accident in the Fukushima Daiichi Nuclear Power Plant (2011), which reminded the world of the potential risks of nuclear energy and the consequences of which continue to have a lasting effect. There is no nuclear power plant in Serbia, but there are about 15 nuclear power stations scattered within its neighboring countries. Therefore, the Serbian Government decided to study how the Serbian public perceives the risks related to the potential construction of nuclear power stations in the country, nuclear energy in general, and its possible benefits and risks. The objective of this paper is to present the results of this assessment along with a literature overview on the (environmental) risk of nuclear power. A pilot study consisted of a series of 270 randomized face-to-face interviews that took place in the public square of Belgrade in March 2019. Logistic regression was used to examine the cumulative effects of the different risk factors. The results showed that the majority of the respondents are skeptical and do not support the construction of nuclear power stations in Serbia. Furthermore, this research identified several additional important correlations that have a significant impact on the public perception of risk.
\end{abstract}

Keywords: nuclear energy; nuclear power; risk perception; disaster; Serbia

\section{Introduction}

Global electricity consumption is projected to increase faster than the estimated overall global energy demand [1]. Therefore, countries have to diversify energy sources in line with their increasing energy needs; however, most energy sources generate pollution elements such as excessive carbon $(C)$ gas. Considering the cyclical changes in geological times, it can be said that human factors as well as planetary mechanisms shape global warming. The global release of excessive carbon (C) gas is now one of the major causes of global warming [2-4]. Owing to the rise in greenhouse gas emissions over the last century, the Earth's surface temperature rose by $1.0-1.2^{\circ} \mathrm{C}$ and the ocean level increased by $20-22 \mathrm{~cm}$ [5]. The search for new/additional/alternative energy sources with low carbon emissions is continuing to reduce the environmental and social costs of electricity generation [6]. Nuclear energy (nuclear power) remains one of the cheapest and potentially most appropriate ways to mitigate the harmful effects of climate change due to its relatively low carbon dioxide emissions.

Nuclear power stations do supply electricity power without damage and change to the environment, but have catastrophic effects when accidents happen, for example, during the 
transportation and storage of radioactive materials [7]. Kristiansen [8] compared different potential technical, economic, social, and environmental advantages and risks of nuclear energy, some of which are serious health threats to humans and animals and damaging to the environment once nuclear fission becomes uncontrollable.

\subsection{Literature Review}

This paper belongs to the literature on (environmental) risk and nuclear power. The definitions of environmental and human risk related to broader resource exploitations and renewables in Central and Eastern Europe are well known [9]; see risks in nuclear power presented by Vlcek et al. [10]. In our paper, we focus on the effects of different demographic, socio-economic, and psychological characteristics of the perception of risk posed by nuclear energy and compare previous findings with a pilot study conducted in Serbia.

Many previous studies [11-13] have identified that individuals with traditional values have greater support for it, while those with altruistic values have greater opposition to nuclear power, showing that values predict attitudes [13]. It has also been found that attitudes toward nuclear power do not vary by gender, age, education, income, or political orientation. In terms of ethnicity, some ethnicities are more supportive than others. Related to gender, there are no consistent results. Some studies found no significant differences for gender [14-16], while others found significant differences [14,17]. Greenberg and Schneider [17] also found that women are more concerned about environmental risks than men. Women in Sweden seem to have greater opposition to nuclear power than men do [18]. There are also other research variables that may relate to the acceptance of risk, such as age [19,20] and marital status [21,22].

The relationship between public attitudes to nuclear power is diverse: some are positive [23], while others are negative [24]. One study conducted in the USA showed that people living around a power plant perceive nuclear energy more positively than people in general due to the benefits they receive, such as in workplaces, etc., [25], while people in China are opposed to nuclear power plants in their area [26]. When people believe that nuclear energy has more benefits for them than detriments, it is more likely to be deemed acceptable [27]. This is reasonable in light of the benefits seen in workplaces and therefore financial security/dependency. The general level of concern has not been correlated with risk perception [11]. On the other hand, it was found that trust in environmental protection institutions and the perceived risk of a global environmental problem do not presuppose principled views on nuclear energy [28-31]. At the same time, it was determined that values are predictors of attitudes; i.e., individuals with traditional values provide more support, while those with altruistic values tend to oppose nuclear energy. Huang et al. [32] formed a structural equation model to describe the level of public acceptance when it comes to nuclear power plants, and identified four risk perception factors: knowledge, perceived risk, benefits, and trust. It was determined that women, persons who are not part of public services, persons with lower incomes, and those who live near a nuclear power plant accept nuclear energy to the least extent. On the other side, strong correlations between social trust and perceived risks and benefits have been observed for hazards of which people have little knowledge [33]. Takebayashi et al. [12] performed a systematic review of the literature and found that governing factors of radiation risk perception included demographics, disaster-related stressors, trusted information, and radiation-related variables and that the effects of radiation risk perception included severe distress, intentions to leave employment or to not return home, among others. Jun, Kim, Jeong, and Chang [34] pointed out that public perception is often an obstacle to the development and implementation of nuclear policies, requiring substantial subsidies that are not based on the social evaluation of nuclear energy. These authors, in research assessing the social value of citizens' readiness to pay for nuclear energy, found that the social evaluation of nuclear energy increases by an average of $68.5 \%$ if adequate information on nuclear energy is provided to the public. It was also proven that the public does not change their perception due to provided information 
or education efforts. Overall, there are 18 factors that influence the public's perception of risk, which need to be taken into account. Knowledge is only one of them. Specific risk perceptions held by a given population and its various subgroups must be acknowledged and incorporated into successful risk communication and public engagement strategies [35]. A significant body of research [33,36-39] has highlighted the importance of institutional trust in influencing risk expectations, i.e., the level of trust in those agents responsible for risk management. In other research, it was found that social trust is a key factor in predicting the perceived risks and benefits of technology, and support was provided for the theory of social trust in the similarity of prominent values [39]. A study conducted in four European countries (Sweden, Spain, the United Kingdom, and France) found that trust is a significant predictor of perceived risk [40]. Moreover, the correlation between the confidence and perception of risks is also varied, e.g., trust generally gave a better explanation of the perceived risk.

In one of the studies, the respondents were asked to evaluate the likelihood of a nuclear disaster at the Krško nuclear power with serious consequences for the environment that would necessitate the evacuation of the nearby population. Most respondents expressed their belief that such a disaster is improbable [41].

Related to preparedness for nuclear disaster, there are a number of papers examining the level of preparedness [42,43] and the factors that affect it [41,44,45]. Despite potential shortcomings in nuclear and radiological event planning and preparedness, it is known that these incidents are increasingly likely to occur [42,43]. In practice, in spite of good planning, communication, and training, it was found [40] that almost three-quarters of the population living within a three-kilometer radius remain unfamiliar with the locations of the reception centers, and two-thirds of them are unfamiliar with the evacuation routes. Hasegawa et al. stressed that, by promoting social capital (e.g., social networks, reciprocal ties, and social participation), people become more likely to engage in disaster-preparedness activities [46].

Despite all the existing knowledge and IAEA Safety Standards that require the operators in Member States to maintain an adequate level of emergency preparedness, the current level of preparedness in Serbia remains low due to a fatalistic attitude, poor nuclear disaster planning, the low attendance of personnel at training sessions, poor coordination, and scarce attention and resources devoted to the management of a possible disaster. The Chernobyl (1986) and Fukushima (2011) nuclear power plants accidents had a substantial impact on nuclear emergency planning and response, as well as on the processes of implementing a modern nuclear emergency management system, which, for example, is currently under way in Germany [45]. Razak, Hignett, and Barnes [47] highlighted that response planning and preparation should be considered at three levels: organizational (policies and procedures), technological (decontamination, communication, security, clinical care, and treatment), and individual (willingness to respond, PPE, knowledge, and competence). Shah, Shahzad, and Afzal [48] found that the medical responders were aware of the consequences of nuclear disaster and were found willing to respond to these kinds of disasters voluntarily, but they were not satisfied with their level of preparedness/awareness about nuclear/radiological disasters. Furthermore, Mortelmans et al. [44] found that there are serious gaps in hospital preparedness for nuclear disasters in Belgium, and a lack of financial resources is a major obstacle in achieving sufficient preparedness. Malešič et al. [41] stressed that respondents believe that their institutions and companies are generally well prepared and able to evacuate those to whom they have a duty of care.

There are many research papers related to the fear of nuclear disaster [49-51]. Nishikawa, Kato, Homma, and Takahara [52] found that residents living near nuclear facilities have shown greater concern about the health risks of nuclear disasters than about the likelihood that such accidents will be caused by human error. In other research, it has been found that public concern and fear increased with greater distance from the site, and this distance effect occurs because people farther away from the site of an accident have less information about it, and this may amplify their fears and reduce their acceptance of nuclear energy [53-55]. 
Safety issues related to the use of nuclear power have been addressed, and how this has contributed to improvements, despite accidents and incidents that have compromised public confidence, has been demonstrated [56]. After the Fukushima Daiichi nuclear power plant accident in 2011, the Japanese government began debating its nuclear strategy $[57,58]$. Right after the Fukushima Daiichi accident, the percentage of those in favor of nuclear energy dropped from $57 \%$ before the accident to $49 \%$ after it [59]. The survey from over 24 countries showed that the respondents were mostly against nuclear power; in addition, $26 \%$ of the respondents expressed that their attitudes were changed in favor of nuclear energy after the accident [60].

\subsection{Historical Issues of Nuclear Power Worldwide}

Since the 1950s, the overall experience with nuclear energy has shown that, as anything else, it has both advantages and disadvantages. Disadvantages that should be considered include radioactive waste and its management as well as possible hazards and accidents, and these impact the environment and society, irrespective of the proximity of its site. The development of nuclear technology has exposed a difference between the excitement for a new, reliable, renewable, and secure energy source reported by scientific experts at the beginning of the early 1960s and the fear of potential nuclear accidents, but also related and still largely unknown long-term health and environmental impacts on the general public [61]. From the very beginning, nuclear power was perceived to be one of the cheapest sources of electricity and was expected to replace coal and become a major source of electricity [62]. Several developed and developing countries use primarily nuclear energy for power production; e.g., the United States, France, China, and the Russian Federation had the most active reactors in the world at the end of 2019 [8]. France is the leading producer of nuclear energy, providing $70.6 \%$ of its total electricity production, followed by Ukraine $(53.9 \%)$, Sweden $(34.0 \%)$, and South Korea (26.2\%) (Table 1). Nuclear power generation in Eastern Europe is very high, approximately 21\%. According to the estimates of the International Atomic Energy Agency (IAEA), it is expected that the electricity generation capacity in Eastern Europe will increase by about 40\% in 2030 [62]. There are currently 443 civil nuclear power reactors in operation around the world, with another 54 under construction, according to the IAEA. At the end of 2019, total net power capacity was $392 \mathrm{GWe}$, accounting for about $10.5 \%$ of the total electricity demand [63,64].

Table 1. Nuclear power plant and nuclear electricity production in some countries, 31 December 2019 [64].

\begin{tabular}{|c|c|c|c|c|c|}
\hline & \multirow{2}{*}{ Country } & \multirow{2}{*}{$\begin{array}{l}\text { Operational } \\
\text { Reactors }\end{array}$} & \multirow{2}{*}{$\begin{array}{l}\text { Reactors under } \\
\text { Construction }\end{array}$} & \multicolumn{2}{|c|}{ Nuclear Electricity Production } \\
\hline & & & & Tw/h & $\%$ of Total \\
\hline \multirow{12}{*}{$\begin{array}{l}\text { Most nuclear electricity } \\
\text { production countries }\end{array}$} & USA & 96 & 2 & 809.4 & 19.7 \\
\hline & France & 58 & 1 & 382.4 & 70.6 \\
\hline & China & 48 & 11 & 330.1 & 4.9 \\
\hline & Russia & 38 & 4 & 195.5 & 19.7 \\
\hline & South Korea & 24 & 4 & 138.8 & 26.2 \\
\hline & Canada & 19 & - & 94.9 & 14.9 \\
\hline & Germany * & 8 & - & 80.1 & 13.0 \\
\hline & Ukraine & 15 & 2 & 78.1 & 53.9 \\
\hline & Japan & 33 & 2 & 65.7 & 7.5 \\
\hline & Sweden & 7 & - & 64.4 & 34.0 \\
\hline & United Kingdom & 15 & 2 & 51.0 & 15.6 \\
\hline & India & 22 & 7 & 40.7 & 3.2 \\
\hline \multirow{7}{*}{$\begin{array}{c}\text { Neighboring countries } \\
\text { of Serbia }\end{array}$} & Bulgaria & 2 & - & 15.9 & 37.5 \\
\hline & Czechia & 6 & - & 28.6 & 35.2 \\
\hline & Hungary & 4 & - & 15.4 & 49.2 \\
\hline & Romania & 2 & & 10.4 & 18.5 \\
\hline & Slovakia & 4 & 2 & 14.3 & 53.9 \\
\hline & Slovenia & 1 & - & 5.5 & 37.0 \\
\hline & TOTAL & 19 & & & \\
\hline
\end{tabular}

* Germany's data are from 2018. 
Despite the growing importance of nuclear energy in view of the growing environmental and fossil fuel supply problems, Ahearne [65] stresses that obstacles to the further development of nuclear energy include costs, concerns about its connection to the proliferation of nuclear weapons, poor public attitudes, inadequate ways of disposing nuclear waste, and a lack of skilled labor. The attitude that the spread of nuclear materials can lead to proliferation risks is a very important obstacle [66]. Some of the most important factors for people's opposition to the introduction of nuclear energy are the lack of knowledge about it and the processes characteristic of production and safety measures [67-69], as well as concerns about climate change. For example, Ertör-Akyazı et al. [70] found that fewer respondents embraced nuclear energy, while many more supported investment in renewable energy. In addition, the authors found that knowledge of the problem of climate change was a common factor that explained the acceptance of both nuclear and renewable energy sources. In China, most respondents are interested in the development of nuclear energy, although public opinion shows a certain level of doubt about the safety of nuclear energy, because they are afraid of nuclear disasters [71]. As barriers to the introduction of nuclear energy, there are also legal barriers that may prohibit the use of nuclear energy for electricity generation, as in the case in Australia [72,73]. Some countries, such as the UK, Turkey, and those with emerging economies (e.g., Malaysia and Indonesia), are increasingly seeking to attract private investors for nuclear projects using project finance [74]. Jewell [75] found that indicators for the potential of nuclear power include the size of the national grid, the presence of international grid connections, and the security of fuel supply for electricity production.

Peters and Slovic [76] found that worldviews and affect-driven imagery together provide an extremely predictable picture when it comes to nuclear energy risk perceptions and support for this type of technology. According to them, affects and worldviews make individual and independent contributions to the prediction regarding nuclear support.

It is relatively easy to raise nuclear opposition through unfavorable incidents, such as mass demonstrations or accidents such as the Three Mile Island, but it is very difficult to increase nuclear support even after long periods of safe activity [13]. Moreover, it was found that the majority of public respondents were not ready to accept the construction of a high-level local nuclear waste storage facility in their region. The public treated the issue of nuclear waste as a very important topic [77]. However, if people do not see a good substitute for technology from which they can enjoy significant benefits, they are willing to take private risks [78]. The French have a higher level of risk perception and a more negative attitude towards nuclear energy than the Dutch. However, the results also show that the benefits of using nuclear energy are higher [16].

According to previous studies, the public acceptance of nuclear power has been influenced by energy safety, risk perception, and profit perception. EU countries producing nuclear power, such as Sweden, the United Kingdom, and the Czech Republic have more acceptance of nuclear energy than countries with no nuclear power plants, such as the Netherlands [79].

However, potential nuclear accidents continue to have a profound impact on the environment and human health, affecting public views and perceptions of nuclear power. The Three Mile Island (1979) in the US, Chernobyl (1986) in Ukraine, and the Fukushima Daiichi nuclear power accidents in Japan (2011) remain the most significant radiological accidents and play an important role in how nuclear energy and government policy is perceived [49].

\section{Materials and Methods}

\subsection{Study Design}

This study examines an explanatory model of the acceptance of nuclear power in Serbia. The main question of the study is to explore the perceptions of the social benefits and risks of nuclear power in the context of Serbia by integrating them into an existing 
model of the acceptability of risks and benefits (Figure 1). Hence, we compared the fear of exposure to radiation with the social benefits of nuclear energy.

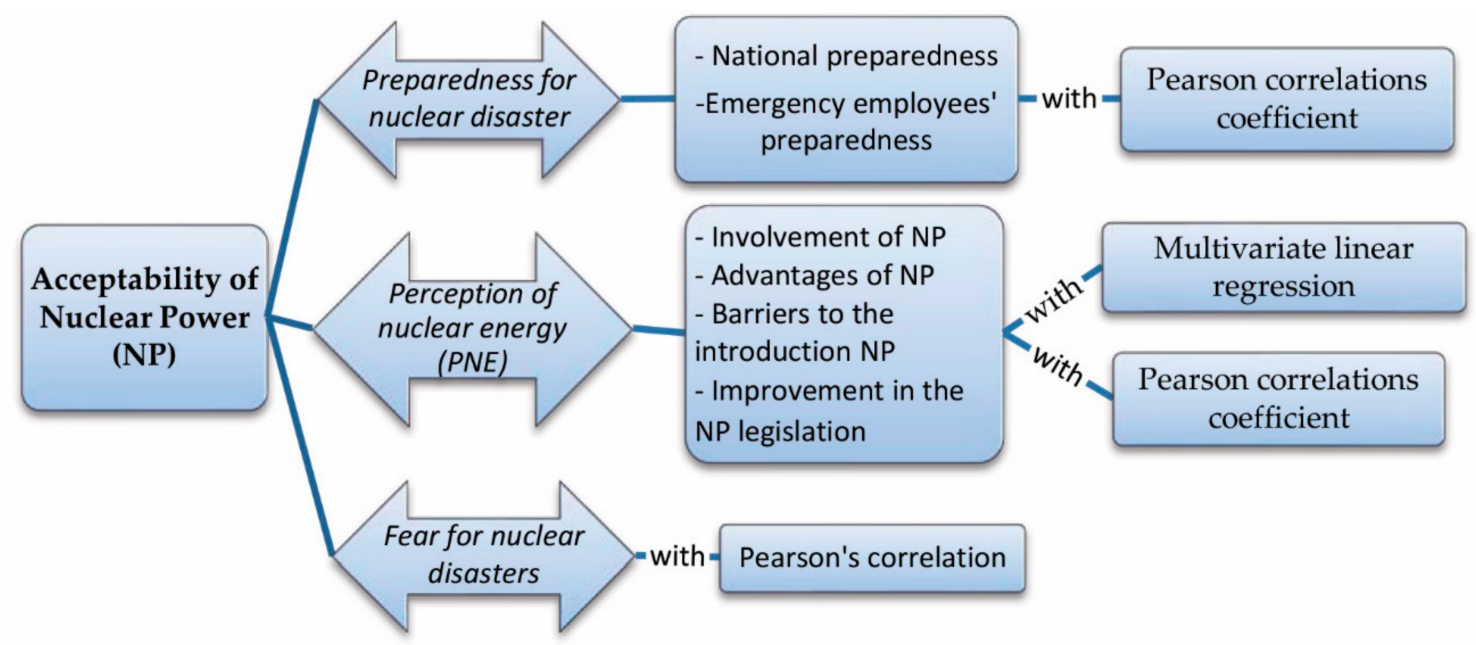

Figure 1. Model of acceptability of nuclear power (nuclear power).

\subsection{Survey Instruments}

This study was conducted using quantitative analysis. Several published survey approaches $[13,32]$ were consulted for the creation of a structured questionnaire tailored to the social and demographic situation of Serbia. The questionnaire consists of demographic information of the participant (e.g., gender, age, educational level, marital status, and employment status) with comprehensive, multiple-choice questions and 5-point Likertscale questions.

The reliability of the overall questionnaire in terms of Cronbach's alpha coefficient is 0.795 . The performance of items in separate scales is lower, but Cronbach's alpha also has values between 0.701 and 0.795 , which are considered to have sufficient reliability coefficients. In order to verify the comprehensibility and usability of the prototype questionnaire, a pilot pre-testing of the questionnaire was carried out in Belgrade in January 2019 with 30 people (participants were chosen randomly around the municipality and questioned in the main public square). Following the pilot analysis, it was determined that the measurement tool should be categorized into three: general public views of nuclear energy, preparedness for nuclear hazard risk, and fear of nuclear accidents. Our research was consistent with the Declaration of Helsinki, outlining the principles for socio-medical research involving human subjects. Additionally, participants provided informed consent to participate in the study. The research protocol was approved by the committees of the scientific research group review board of the Scientific-Professional Society for Disaster Risk Management and International Institute for Disaster Research, ID-25062020.

The public's perception and behavioral reactions to nuclear power have been well known since the 1970s and, therefore, remain an important part of political decision making in every country around the world, primarily due to the nature of the feelings linked to subjective perceptions of risk $[35,79,80]$. Any nuclear power plant is at risk of an incident or an accident [8]. When an incident happens on a scale of 4-7, it usually affects both short- and long-term energy security in the country and may result in an ad hoc energy policy and an increased demand worldwide for fossil fuels and/or natural gas, as in Japan. Many European countries, such as Germany, Italy, or Switzerland, were also affected by the Fukushima disaster in 2011 by the immediate shutdown of some of the nuclear reactors or the abandonment of plans to build new ones, not only because of a loss of public acceptance of nuclear power $[81,82]$. However, two years after the Fukushima nuclear accident, it was found that there was no significant difference in the perception of nuclear energy in British society [83]. 


\subsection{Study Area}

The Republic of Serbia is situated at the crossroads of Central and Southeastern Europe on the Southern Pannonian Plain and the Central Balkans, and it is also located at the confluence of the Sava and the Danube Rivers. Belgrade is the capital of the Republic of Serbia (Figure 2). At the end of 2018, there were 1,690,193 people living in Belgrade (24\% of the total population of Serbia) [84].

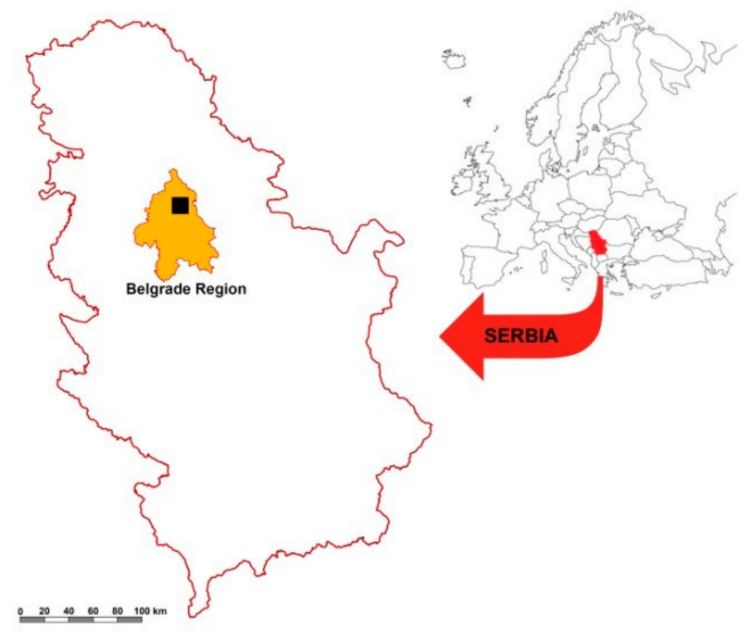

Figure 2. Study area [85].

Serbia itself does not have nuclear power, but there are 19 nuclear power plants in operation in neighboring countries (Hungary, Slovenia, Bulgaria, Romania, Slovakia, and Czechia). It is extremely close to Serbia to Kozloduy (Bulgaria), Krsko (Slovenia), and Paks (Hungary). At the end of 2019, nuclear power generated 37.5\% of the country's electricity in Bulgaria, 35.2\% in Czechia, $49.2 \%$ in Hungary, $53.9 \%$ in Slovakia, 37\% in Slovenia, and $18.5 \%$ in Romania [46]. The Serbian Government is considering the development of nuclear power programs or plans as a policy option. As the authorities and policy makers want to provide their people with the cheapest energy options, the Serbian government wants to know what the public thinks about nuclear power and the potential establishment of the country's nuclear power.

With the approval of the Law on the Prohibition of the Construction of nuclear power plants in the Federal Republic of Yugoslavia [86], a moratorium has been imposed in Serbia and prohibits not only the construction of nuclear power plants but also their development. The prohibition also extends to investment decisions, the implementation of investment plans, and technical documents for the construction of nuclear power plants, nuclear fuel production plants, and spent nuclear fuel processing plants. Due to this ban, the study of nuclear technology in higher education institutions was minimized.

Although Serbia does not have a nuclear power plant, there is an early warning system for nuclear accidents, and Serbia is part of a network establishment by the IAEA. The Adoption of the Radiation Safety and Security Law $[87,88]$ and the signing with Russia of two agreements on the use of nuclear energy for peace-time purposes-one on the preparation of the public and the development of a positive public opinion on the use of nuclear energy for peace-time purposes, and another on the training of staff for the use of nuclear energy for peace-time purposes-also support the creation and development of nuclear installations. It also envisages increasing the qualifications of administrative, scientific, and technical staff in the field of peaceful use of nuclear energy through training and internships, and enhancing the general knowledge and use of nuclear technology by citizens in other areas. Furthermore, no surveys have been carried out in Serbia to examine the views of citizens on the different viewpoints of the use of nuclear energy for peacetime purposes. 


\subsection{Sample}

The trial research was conducted on 17 March 2019 and consisted of 270 randomized face-to-face interviews in the public square of Belgrade, Serbia. The participants were chosen using the snowball sampling technique. The sample was convenient and not necessarily representative of Serbia's entire population, but they only provided an opinion on this topic of the study. Snowball sampling is a technique of convenience used when reaching subjects with the target features is difficult [89]. Out of a total of 360 respondents, 285 agreed to participate in the survey, while 90 refused (so the total response rate was $79.16 \%$ ). Of the total number of respondents who agreed to participate in the survey, 270 respondents completed the survey questionnaire, 15 respondents did not (the completion rate was $94.73 \%$ ). The sample was $58.8 \%$ (159) male and $41.1 \%$ (111) female (there are $51.3 \%$ women and $48.7 \%$ men in the country in total), with an average age of 38 years (country averages: men: 41.2; women: 43.9). Of the participants, $60 \%$ (162) were between 18 and 38 years of age, and $27.8 \%$ were between 39 and 59 years of age. Out of the $59.3 \%$ that had finished compulsory education (160), $40.7 \%$ had university or higher education (with primary school at $20.76 \%$, high school at $48.93 \%$, junior college at $4.51 \%$, and undergraduate at $10.59 \%$ of the study population). Married persons accounted for $62.1 \%$ (167) of the study, while $37.9 \%$ were single. The majority of respondents were unemployed (Table 2). The research focused on the public perception of nuclear power, i.e., fear and profit. The opinions of all participants are considered important for policy makers and scientists in terms of the development of nuclear power and the design of nuclear power plants. In the survey, all participants were voters, since the legal age of voting in Serbia is 18. Leaders and policy makers consider all the views of the electorate, so we selected adults for this analysis. Other variables included gender, educational level, marital status, and employment. The literature related to these variables was included in the selection process.

Table 2. Basic demographic and socio-economic information for respondents.

\begin{tabular}{|c|c|c|c|}
\hline Variable & Category & f & $\%$ \\
\hline \multirow{2}{*}{ Gender } & Male & 159 & 58.8 \\
\hline & Female & 111 & 41.1 \\
\hline \multirow{3}{*}{ Age } & Young (18-38) & 162 & 60 \\
\hline & Middle-aged (39-59) & 75 & 27.8 \\
\hline & Older (60-68) & 33 & 12.2 \\
\hline \multirow{2}{*}{ Education level } & Compulsory education ${ }^{1}$ & 160 & 59.3 \\
\hline & University and higher ${ }^{2}$ & 110 & 40.7 \\
\hline \multirow{2}{*}{ Marital status } & Single & 103 & 38.2 \\
\hline & Married & 167 & 61.8 \\
\hline \multirow{3}{*}{ Employment status } & Yes & 98 & 36.5 \\
\hline & No & 172 & 63.5 \\
\hline & Total & 270 & 100 \\
\hline
\end{tabular}

${ }^{1}$ Compulsory education in Serbia is 10 years: Primary school (3 years) + Secondary school (4 years) + High school diploma (3 years). ${ }^{2}$ University and higher: Bachelor's degree, Master's degree, Ph.D., or equivalent.

\subsection{Analyses}

Statistical analysis of the data was conducted using the Social Sciences Statistical System (SPSS 20, IBM, Armonk, NY, USA). In the mentioned program, all data obtained by the survey were arranged and classified. Using descriptive statistical analyses, the distributions of answers to the questions were determined. The internal consistency of the Likert scales for the five items was strong with a Cronbach's alpha of 0.78. To test the perception of nuclear power, logistic regression was used in the first step to test the combined effects of the various factors included in the proposed model (age, gender, 
marital status, income level, and educational level). The Pearson correlation was used to test the relationship between all demographic variables and the measurement factors. This research was limited to the subject and the measurement used throughout the sample in which the study was conducted.

\section{Results}

The study's findings are discussed in three dimensions:

- Perceptions of nuclear energy;

- Perceptions of the preparedness for nuclear disasters;

- $\quad$ Perceptions of fear of nuclear accidents.

\subsection{Perception of Nuclear Energy}

Four dependent variables (nuclear energy perception, advantages of nuclear energy usage, barriers to nuclear energy adoption, and changes to legal regulations) were included in the multivariate logistic regression model. In the first step, logistic regression was used to determine the combined effects of the various factors included in the proposed model (gender, marital status, income level, and educational level) (Table 3). The logistic regression model applied to the nuclear energy component (with all predictors) was statistically significant $\left(\chi^{2}=66.54 ;(4, N=270), p \leq 0.01\right)$ and explains the variance between $21.8 \%$ (Cox and Snell) and 29.8\% (Nagelkerke). Regression results indicated that the three predictors had a statistically significant contribution to the model (gender, marital status, and educational level; $p \leq 0.01$ ). The educational level was found to be the strongest predictor of the involvement of nuclear energy with a regression coefficient of 3.20. This meant that respondents who had been educated in college objected to the implementation of nuclear energy over three-times more often than those who had not been educated in college, with all other factors becoming equal to the standard (Table 3).

The model, including the advantages of using the knowledge variable for nuclear power (with all predictors), was statistically significant $\left(\chi^{2}=69.67 ;(4, \mathrm{~N}=270), p \leq 0.01\right)$ and explains the variance between 13.7\% (Cox and Snell) and 20\% (Nagelkerke). Regression results indicated that the three predictors made a statistically significant contribution to the model (marital status and gender, $p \leq 0.05$; employment status, $p \leq 0.01$ ). Employment status was found to be the strongest predictor of the advantages of using nuclear energy variable with a regression coefficient of 5.13. Employee participants stated that the electricity supply was reliable in reaction to a description of the benefits of the implementation of nuclear energy over five-times more often than those who did not work in the same environment with all other variables.

Table 3. Multivariate binary logistic regression analyses relevant to the public perception of nuclear energy.

\begin{tabular}{|c|c|c|c|c|c|c|c|c|c|c|c|c|}
\hline \multirow[t]{2}{*}{$\begin{array}{l}\text { Predictor } \\
\text { Variable }\end{array}$} & \multicolumn{3}{|c|}{$\begin{array}{c}\text { Involvement of Nuclear } \\
\text { Power }\end{array}$} & \multicolumn{3}{|c|}{ Advantages of Nuclear Power } & \multicolumn{3}{|c|}{$\begin{array}{c}\text { Barriers to the } \\
\text { Introduction of Nuclear } \\
\text { Power }\end{array}$} & \multicolumn{3}{|c|}{$\begin{array}{l}\text { Improvement in Nuclear } \\
\text { Power Legislation }\end{array}$} \\
\hline & $\beta$ & SE & $\operatorname{Exp}(B)$ & $\beta$ & SE & $\operatorname{Exp}(B)$ & $\beta$ & SE & $\operatorname{Exp}(B)$ & $\beta$ & SE & $\operatorname{Exp}(B)$ \\
\hline Gender & $-1.30 * *$ & 0.316 & 0.271 & $-0.724 *$ & 0.331 & 0.485 & $-1.45 *$ & 0.503 & 0.234 & -0.353 & 0.273 & 0.703 \\
\hline $\begin{array}{l}\text { Employment } \\
\text { status }\end{array}$ & -0.077 & 0.294 & 0.926 & $1.63^{* *}$ & 0.327 & 5.13 & $2.80 * *$ & 0.563 & 16.56 & $0.857^{* *}$ & 0.265 & 2.35 \\
\hline Marital status & $-1.95^{* *}$ & 0.124 & 0.142 & $-1.08 *$ & 0.328 & 0.365 & $1.52 *$ & 0.619 & 6.03 & $-0.603 *$ & 0.271 & 0.547 \\
\hline Education level & $-1.69^{* *}$ & 0.472 & 3.20 & 0.678 & 0.523 & 1.97 & $-1.35 *$ & 0.585 & 5.39 & 0.035 & 0.403 & 1.03 \\
\hline
\end{tabular}

On the other hand, the model that included barriers to the introduction of nuclear power information variables (with all predictors) was statistically significant $\left(\chi^{2}=49.70 ;(4\right.$, $\mathrm{N}=270) p \leq 0.000$ ) and explained between 16.8\% (Cox and Snell) and 31.7\% (Nagelkerke) of the variance. Regression results showed that the four predictors made a statistically significant contribution to the model (gender, marital status, and educational level, $p \leq 0.05$; employment status, $p \leq 0.01)$. Employment status was the strongest predictor of the 
16.56 odds ratio of obstacles to the adoption of nuclear power. Specifically, employed respondents stated that the downsides of the implementation of nuclear power are expressed in potential sources of radioactive radiation more than 16 times more often than those not employed in terms of all other variables of equal value in the model.

The model that included the improvement in the nuclear power legislation for all predictors was statistically significant $\left(\chi^{2}=16.81 ;(4, N=270), p \leq 0.01\right)$ and explains between $6 \%$ (Cox and Snell) and 8.2\% (Nagelkerke) of the variance. Regression results showed that the two predictors made a unique and statistically significant contribution to the model (employment status, $p \leq 0.01$; marital status, $p \leq 0.05$ ). Employment status was found to be the strongest predictor of changes to legal regulation with an odds ratio of 2.35. Employed respondents, therefore, responded that they are in favor of changes to nuclear legislation over two-times more often than those who were not employed, with all other factors equal to the standard (Figure 3).

The majority of respondents (63\%) were opposed to the proposed introduction of nuclear energy in Serbia, compared to $37 \%$ who were in favor. Further analyses showed that there was a small positive association between the attitude of respondents with regard to gender-based nuclear energy $(r=0.287, p \leq 0.01)$ and a negative correlation with marital status $(r=-0.388, p \leq 0.01)$. It was also found that women $(77.8 \%)$ did not support the implementation of nuclear energy compared to men (22.2\%). In comparison, married respondents $(88 \%)$ favored the implementation of nuclear energy more than those who were single $(12 \%)$. There was no statistically significant difference between the level of education and the employment status for opinions of nuclear energy (Table 4).

The predictors of risk perception related to NP

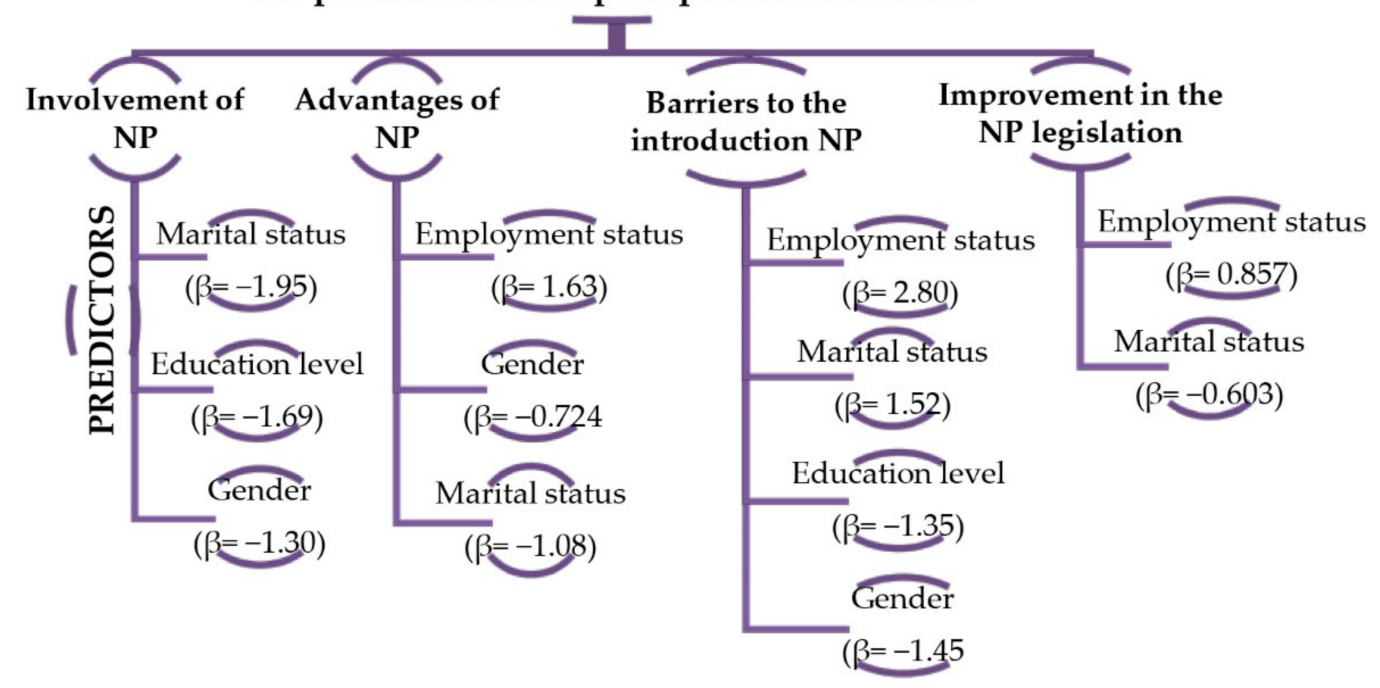

Figure 3. The predictors of risk perception related to nuclear power.

Analyzing the respondents' views on the advantages and disadvantages of using nuclear energy, it was found that the largest number of respondents $(47.6 \%)$ stated that the benefit of using the experiment was a stable and reliable source of electricity, while that of the least environmental importance was given to environmentally sustainable energy $(9.5 \%)$ as an advantage in its use. The respondents also shared their understanding of the threat to the implementation of nuclear energy, and it was found that $52.4 \%$ of respondents thought that the use of nuclear energy could cause a technical failure, $25.4 \%$ stated that there would be a serious problem with radioactive waste, and 19\% believed that there would be a serious problem with nuclear waste. More analyses found that there was a slight association between respondents' perceptions of the advantages of implementing gender-based nuclear energy $(r=-0.124, p \leq 0.05)$, employment status $(r=0.234, p \leq 0.01)$, and marital status $(r=-0.202, p \leq 0.01)$. There was no statistically significant difference 
between the level of education and the benefits of nuclear energy usage (Table 3). The majority of respondents who were married (40.7\%) or were unemployed $(41.5 \%)$ stated that the advantage of using nuclear energy is that it is a stable and reliable source of electricity, while non-married respondents $(36.7 \%)$ and workers (34\%) stated that the downside is that the type of energy is environmentally friendly and low pollution.

Men (44\%) stated that the use of nuclear energy was a safe and efficient source of energy more often than women, while women $(30.2 \%)$ stated that it would contribute to lower electricity prices more often than men. In the end, it was found that women were more likely than men to state that the use of nuclear energy was more environmentally acceptable and would lead to a reduction in negative impacts on climate change. As regards the barriers to the implementation of the nuclear energy, it was identified that there was a link between the employment status of respondents $(r=0.332, p \leq 0.01)$ and the level of education $(r=-0.197, p \leq 0.01)$. However, there was no statistically significant difference between sex and marital status related to the obstacles to the implementation of the nuclear energy. The majority of faculty-educated people (57.3\%) reported the potential of a nuclear disaster, while secondary school respondents $(22.2 \%)$ said there was a lack of a radioactive source of radiation. It was found that men were more likely than women to state that the main problems of nuclear energy were the risk of a nuclear accident and the risk of using radioactive materials for terrorist purposes. Women, on the other hand, stated more often than men that the main problem was the production of radioactive waste and the source of radioactive radiation.

Table 4. Pearson's correlation results between the perception of public nuclear energy and predictor variables.

\begin{tabular}{|c|c|c|c|c|c|c|c|c|c|c|}
\hline \multirow[t]{2}{*}{ Variable } & \multicolumn{2}{|c|}{$\begin{array}{l}\text { Involving Nuclear } \\
\text { Energy }\end{array}$} & \multicolumn{2}{|c|}{$\begin{array}{l}\text { Advantages of } \\
\text { Nuclear Energy }\end{array}$} & \multicolumn{2}{|c|}{$\begin{array}{l}\text { Barriers to the } \\
\text { Introduction of } \\
\text { Nuclear Energy }\end{array}$} & \multicolumn{2}{|c|}{$\begin{array}{l}\text { Improvement in } \\
\text { Nuclear Power } \\
\text { Legislation }\end{array}$} & \multicolumn{2}{|c|}{$\begin{array}{l}\text { Possibilities of } \\
\text { Nuclear Disaster }\end{array}$} \\
\hline & Sig. & $r$ & Sig. & $r$ & Sig. & $r$ & Sig. & $r$ & Sig. & $r$ \\
\hline Gender & $0.000 * *$ & 0.287 & 0.042 & $-0.124 *$ & 0.870 & 0.010 & 0.164 & -0.085 & 0.144 & $-0.089 * *$ \\
\hline Employment status & 0.154 & 0.071 & 0.000 & $0.234^{* *}$ & 0.000 & $0.332 * *$ & 0.003 & $0.189 * *$ & 0.107 & -0.098 \\
\hline Marital status & $0.000 * *$ & -0.388 & 0.001 & $-0.202 * *$ & 0.097 & 0.101 & 0.023 & $-0.138^{*}$ & 0.010 & $-0.156 *$ \\
\hline Education level & 0.325 & 0.060 & 0.194 & -0.079 & 0.001 & $-0.197 * *$ & 0.560 & -0.036 & 0.000 & $0.378^{* *}$ \\
\hline
\end{tabular}

${ }^{*} p=0.05 ; * * 0.01$.

Starting with the current moratorium on nuclear power plant construction in Serbia, respondents were asked if they thought the law should be modified to enable nuclear power plant construction. According to the findings, $60 \%$ of respondents were opposed to a $40 \%$ nuclear power law amendment. Since only $37 \%$ of respondents in this study were in favor of nuclear energy being installed in Serbia, it was necessary to look more deeply into why so few people were in favor of a change in the law. More analyses found that the attitudes of respondents were correlated to job status $(r=0.189, p \leq 0.01)$ and marital status $(r=-0.138, p \leq 0.05)$. There was no statistically relevant difference between gender and educational rates. Employed persons (50.9\%), as opposed to unemployed persons $(32.9 \%)$, do not support the establishment of nuclear energy to a greater degree. The study examined the impact of marital status and found that married respondents $(65.1 \%)$ favored the adoption of nuclear energy more than unmarried respondents.

Additionally, the perception of the probability of nuclear accidents in the country was analyzed, and it was found that $32.4 \%(x=2.98)$ of the participants stated that a nuclear accident tragedy is likely to happen. The results of the study revealed that the attitudes of respondents were correlated to gender $(r=-0.089, p \leq 0.05)$, marital status $(r=-0.156$, $p \leq 0.01)$, and educational level $(r=0.378, p \leq 0.01)$. There was no statistically significant difference between employment status and considering a nuclear disaster a possible threat (Table 4). Men $(x=2.90$, sd $=0.992)$ interpreted the level of risk from nuclear disasters differently to women $(x=3.06, \mathrm{sd}=0.777)$ which is similar to those who were married $(x=2.87$, sd $=0.915)$, who perceived a greater risk compared to those who were not married 
$(x=3.16$, sd $=0.846)$. Employed people $(x=3.11, \mathrm{sd}=0.805)$, compared to those who are not $(x=2.11, \mathrm{sd}=1.00)$, consider the level of risk of nuclear hazards to be greater.

\subsection{Perception of Preparedness for Nuclear Disasters}

The public's views of nuclear disaster preparedness were also examined in this study. In this context, people's perceptions of the ability of the government and those who work in emergency services to prepare for nuclear disasters were examined. According to the results, $68.1 \%$ of the respondents thought that the government could be prepared, and more than half $(53.4 \%)$ of the respondents thought that emergency personnel could be prepared (Figure 4). The mean value of the government's preparedness perception $(x=2.01$; $\mathrm{sd}=1.08)$ is lower than the mean value of the preparedness of emergency employees $(x=2.47 ; \mathrm{sd}=1.12)$. Additionally, $13 \%$ of participants believe that the government is unprepared, and $20 \%$ believe that emergency employees are unprepared.

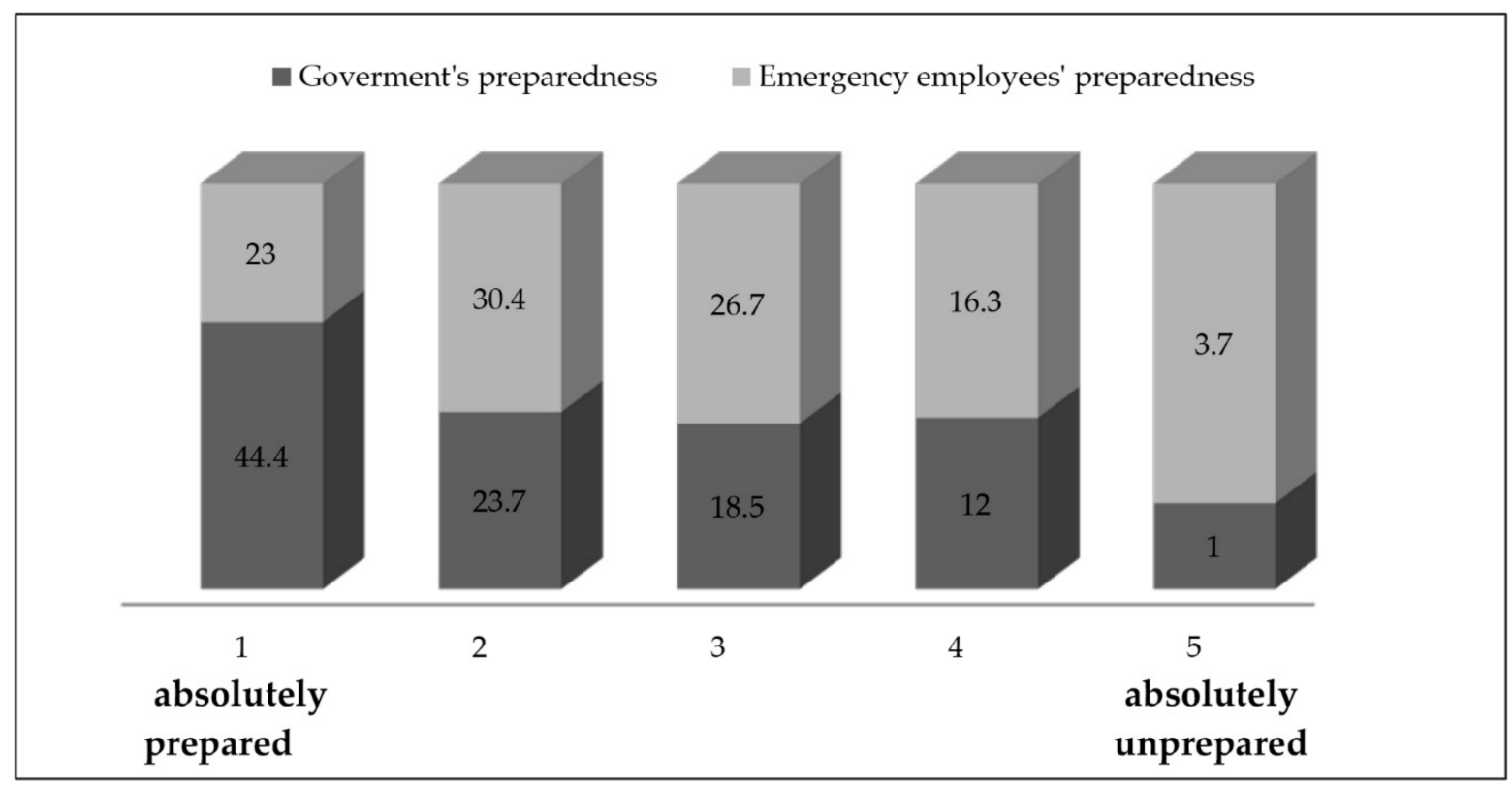

Figure 4. Public's opinion of the government's and emergency service personnel's preparedness for nuclear (\%) disasters.

The results found that there was a correlation between the perception of government's preparedness for nuclear disasters and gender $(r=0.144, p \leq 0.05)$, marital status $(r=0.248$, $p \leq 0.01)$, and educational level $(r=0.164, p \leq 0.01)$. There was no statistically significant difference between employment status and the perception of government's preparation (Table 5). Men $(x=2.15$, sd $=1.01)$ were more positive than women $(x=1.84, \mathrm{sd}=1.13)$ about the government's ability to manage a nuclear disaster.

Table 5. Perception of the participants; Pearson's correlation between government's and emergency employees' preparedness and the variables.

\begin{tabular}{ccccc}
\hline \multirow{2}{*}{ Variable } & \multicolumn{2}{c}{ Government's Preparedness } & \multicolumn{2}{c}{$\begin{array}{c}\text { Emergency Employees' } \\
\text { Preparedness }\end{array}$} \\
\cline { 2 - 5 } & Sig. & $\boldsymbol{r}$ & Sig. & $r$ \\
\hline Gender & 0.018 & $0.144^{*}$ & 0.203 & 0.078 \\
Employment status & 0.079 & $0.107^{* *}$ & 0.008 & $0.161^{* *}$ \\
Marital status & 0.000 & $0.248^{* *}$ & 0.006 & $0.168^{* *}$ \\
Education level & 0.007 & $0.164^{* *}$ & 0.005 & $0.165^{* *}$ \\
\hline
\end{tabular}

${ }^{*} p=0.05 ;{ }^{* *} p \leq 0.01$. 
Additionally, respondents who were married $(x=2.21$, sd $=1.13)$ were more likely to assess the level of government's preparedness compared to those who were unmarried $(x=1.65, \mathrm{sd}=0.875)$. In contrast, regarding educated persons $(x=2.08, \mathrm{sd}=1.12)$, relative to those who were not $(x=1.56, \mathrm{sd}=0.607)$, the findings revealed a correlation between respondents' attitudes regarding their employment status $(r=0.161, p \leq 0.01)$, marital status $(\mathrm{r}=0.168, p \leq 0.01)$, and educational level $(r=0.165, p \leq 0.01)$ and emergency employee preparedness. According to the findings, the perceptions of the participants regarding emergency personnel's preparedness for nuclear disasters do not differ according to the gender of the personnel. Employed persons, on the other hand, have a higher mean $(x=2.70, \mathrm{sd}=1.00)$ than unemployed persons $(x=2.33$, $\mathrm{sd}=1.17)$. Similarly, married participants $(x=2.62$, sd $=1.16)$ thought emergency services $(x=2.22$, $\mathrm{sd}=1.00)$ were better trained than single persons.

\subsection{Perception of Fear of Nuclear Disasters}

Respondents were asked to answer whether they were afraid of potential nuclear accidents. It was found that $71.9 \%$ of the respondents were afraid of such incidents. The overall projected hazard of a nuclear accident is $3.09(\mathrm{sd}=1.19)$. Results showed a correlation between nuclear disaster anxiety and gender $(r=-0.353, p \leq 0.01)$. There was no statistically significant difference between employment status, marital status, or level of education (Table 6$)$. Men $(x=2.15, \mathrm{sd}=1.01)$ were more afraid of nuclear accidents than women $(x=1.84, \mathrm{sd}=1.13)$.

Table 6. Pearson's correlation between fear of nuclear disaster and variables.

\begin{tabular}{ccc}
\hline & Fear of Nuclear Disaster & \\
\hline Variable & Sig. & $r$ \\
\hline Gender & 0.000 & $-0.353^{* *}$ \\
Employment status & 0.883 & -0.009 \\
Marital status & 0.940 & 0.005 \\
Education level & 0.438 & 0.047 \\
\hline
\end{tabular}
$\overline{* *} p \leq 0.01$

\section{Discussion}

Risk analysis research on the threat of nuclear and radiation hazards is not new $[33,39,89]$, with debates focused mainly on the possibility of threat of attack by nuclear weapons, followed by nuclear waste and potential nuclear energy plant accidents [90]. Previous research [11-13] has examined public risk perception with regard to the potential unintentional release of radiation from nuclear facilities (e.g., disposal of nuclear power waste, etc.) Other efforts are focused on the development of standard terminology for radiological protection under the auspices of the International Commission on Radiological Protection (ICRP) [91-95]. Since the 1950s, nuclear energy has been considered by some to be a dangerous technology due to its unknown and invisible nature, therefore, posing a catastrophic threat to society and national survival [96]. Other research studies showed that public opinion plays an important role in determining local, regional, and federal nuclear energy policy $[97,98]$. As a result, policy makers and scientists have been influenced by the public perception of the safety and true threat posed by nuclear power [61]. People generally have both positive and negative views of nuclear power [76].

This study has demonstrated that the majority of respondents of the trial study do not support the implementation of nuclear energy in the Republic of Serbia. This finding was not unexpected due to knowledge by the survey participants of three major accidents with a global impact: Three Mile Island in 1979, Chernobyl in 1986, and Fukushima in 2011. However, our findings were more nuanced. Past research on public acceptance of nuclear power stations has generally focused on overall local community awareness and approval, based on pre-existing beliefs and attitudes regarding the nature of nuclear energy and radiological hazards [89,99-103]. Other studies, however, examined the acceptance of 
nuclear power plants only at specific locations [99]. Furthermore, previous research has shown that public attitudes towards nuclear power vary: some are positive [66], while others are negative [24,98].

Acceptance of nuclear power stations also influences people's confidence in official nuclear organizations and government agencies responsible for public safety $[97,98]$. Our study showed that most of the questionnaire respondents in Serbia were worried about possible nuclear accidents. It can be assumed that the citizens of Serbia do not have enough trust in institutions and organizations (e.g., regulators/operator) that regulate and/or produce nuclear technology [33]. Such findings are consistent with the results of past studies in Germany, Italy, and Switzerland, which showed that some nuclear reactors had been shut down for safety concerns, and new nuclear power plant construction had been abandoned due to the Fukushima accident, a result of the March 2011 earthquake and tsunami. For these reasons, it is necessary to improve risk-related information, bearing in mind that it affects how we perceive risks and what risk decisions we ultimately make [8]. Moreover, a suggestion is made to deploy an iterative continuous improvement model for incorporating specific risk perceptions, held by a given population and its various subgroups, into existing and future risk communication programs in concert with mutualgain-based public engagement mechanisms [35].

Public acceptance of nuclear power is positively linked to strong community awareness of the benefits of nuclear energy sources [101] and trust in government safety agencies, but was negatively linked to strong community perceptions of risks outweighing any benefits of nuclear energy sources. When people perceived a lower risk, they felt that they were gaining more from the nuclear power plant while having more trust and confidence in information about nuclear power provided by government energy agencies and private sector nuclear power companies [104,105]. De Groot et al. [104] concluded that the perception of benefits was key in explaining the high public acceptance of nuclear power, while public risk perceptions of great danger posed by nuclear hazards resulted in a decrease in community acceptance of nuclear energy technology.

Our results demonstrated that the educational level of respondents was the strongest regression coefficient predictor of acceptance of nuclear energy. This finding is consistent with the results of [32] on the importance of knowledge and education regarding acceptance of the benefits of access to nuclear energy despite the recognized hazards. On the other hand, other studies concluded that the public acceptance of the risks of technological disasters caused by nuclear power were unaffected by educational level or general knowledge of the nuclear power industry due to unaddressed risk perception factors held by a given population and its various subgroups, especially in the existing exposure situations [101].

In Serbia, due to traditional factors, women were found to be less likely than men to support nuclear energy [106]. Our study demonstrated that women in general tended to believe that nuclear energy and radioactive waste are less safe and pose a greater hazard to the community than men, and they also tended to believe that the global threat from nuclear weapons is greater than men do [107-110]. Interestingly, our research here showed that men have a statistically significant greater fear of nuclear power plant accidents than women.

The methodological limitations of our study include (1) the potential bias in selecting study subjects for the questionnaire and its completion, (2) the lack of knowledge or experience of the study participants with sources of nuclear energy in their communities, (3) the insufficient representativeness of our sample to the general population of Serbia, and (4) the respondents' fearful mental state caused by the nature of this study relating to nuclear power plan catastrophes.

\section{Conclusions}

The main focus of this research project was the opinions of the people of the Republic of Serbia, a Balkan country, in terms of the potential risks of nuclear power. The selection of the Republic of Serbia for such a study is important to note because nuclear energy is 
not used at all in Balkan countries; as a result, few hazard studies have been conducted by social science investigators in Serbia. As many countries in Europe depend on nuclear energy, the results of our study will prove valuable for government policy makers in other Balkan countries and in Serbia itself, considering the potential construction of nuclear power reactors in the future. Additionally, these findings will play a significant role in educating scientists and the public regarding the risks and benefits of nuclear energy.

Considering that some variables, such as gender, employment status, educational level, and marital status, are important in predicting nuclear energy acceptance, future studies should focus on these variables, as they are useful for all emergency managers and government decision makers grappling with the need for more energy sources in their countries.

As nuclear power represents both an energy source and a potential threat to the environment and to human safety and security, further scientific studies exploring economic and geopolitical factors, such as the unregulated and uncontrolled development of nuclear power, which can lead to irrevocable harm to communities in Serbia, other Balkan countries, and Europe overall, need to be carried out.

Author Contributions: V.M.C. conceived the study idea and developed the study design. The scale was developed by A.Ö., E.K.N., N.N., V.M.C. and G.M. contributed to questionnaire dissemination. A.Ö. managed and drafted the methodology. V.M.C. managed all data, and A.Ö. assisted V.M.C. in analyzing and interpreting the data. Y.L. also contributed to drafting the introduction, A.Ö., E.K.N. and Y.L. drafted the discussion, and V.M.C. contributed to the discussion. All authors have read and agreed to the published version of the manuscript.

Funding: The research was funded by the committees of the scientific research group review board of the Scientific-Professional Society for Disaster Risk Management and International Institute for Disaster Research, ID-25062020.

Institutional Review Board Statement: The study was conducted according to the guidelines of the Declaration of Helsinki and approved by the Institutional Review Board of Scientific-Professional Society for Disaster Risk Management and International Institute for Disaster Research.

Informed Consent Statement: Informed consent was obtained from all subjects involved in the study.

Acknowledgments: The authors thank all collaborators involved in this study. The authors also express their gratitude to the anonymous reviewers for their comments.

Conflicts of Interest: The authors declare no conflict of interest.

\section{References}

1. BP plc. Statistical Review of World Energy, 68th ed.; BP plc: London, UK, 2019. Available online: https://www.bp.com/content/ $\mathrm{dam} / \mathrm{bp} / \mathrm{business}$-sites/en/global/corporate/pdfs/energy-economics/statistical-review/bp-stats-review-2019-full-report. pdf (accessed on 23 March 2021).

2. Naser, H. Analyzing the long-run relationship among oil market, nuclear energy consumption, and economic growth: An evidence from emerging economies. Energy 2015, 89, 421-434. [CrossRef]

3. Poortinga, W.; Aoyagi, M.; Pidgeon, N.F. Public perceptions of climate change and energy futures before and after the Fukushima accident: A comparison between Britain and Japan. Energy Policy 2013, 62, 1204-1211. [CrossRef]

4. Sharma, A.; Srivastava, J.; Kar, S.K.; Kumar, A. Wind energy status in India: A short review. Renew. Sustain. Energy Rev. 2012, 16, 1157-1164. [CrossRef]

5. NASA. Global Climate Change, Global Temperature. 2021. Available online: https://climate.nasa.gov/vital-signs/globaltemperature/ (accessed on 7 April 2021).

6. Abolhosseini, S.; Heshmati, A. The main support mechanisms to finance renewable energy development. Renew. Sustain. Energy Rev. 2014, 40, 876-885. [CrossRef]

7. Zhu, W.; Wei, J.; Zhao, D. Anti-nuclear behavioral intentions: The role of perceived knowledge, information processing, and risk perception. Energy Policy 2016, 88, 168-177. [CrossRef]

8. Kristiansen, S. Media and Risk: A Phase Model Elucidating Media Attention to Nuclear Energy Risk; Universitätsverlag Ilmenau: Münster, Germany, 2017; Volume 5.

9. Pavlínek, P.; Pickles, J. Environmental Transitions: Transformation and Ecological Defense in Central and Eastern Europe; Routledge Press: London, UK, 2000. 
10. Vlcek, T.; Jirusek, M.; Henderson, J. Risk assessment in construction process in nuclear sector within the Central and Eastern Europe. Int. J. Energy Econ. Policy 2015, 5, 482-493.

11. Sjöberg, L.; Drottz-Sjöberg, B.M. Knowledge and risk perception among nuclear power plant employees. Risk Anal. 1991, 11, 607-618. [CrossRef] [PubMed]

12. Takebayashi, Y.; Lyamzina, Y.; Suzuki, Y.; Murakami, M. Risk perception and anxiety regarding radiation after the 2011 Fukushima nuclear power plant accident: A systematic qualitative review. Int. J. Environ. Res. Public Health 2017, 14, 1306. [CrossRef] [PubMed]

13. Whitfield, S.C.; Rosa, E.A.; Dan, A.; Dietz, T. The future of nuclear power: Value orientations and risk perception. Risk Anal. 2009, 29, 425-437. [CrossRef] [PubMed]

14. Mohai, P. Gender differences in the perception of most important environmental problems. Race Gend. Class 1997, 5, 153-169.

15. Siegrist, M. The influence of trust and perceptions of risks and benefits on the acceptance of gene technology. Risk Anal. 2000, 20, 195-204. [CrossRef]

16. Wiegman, O.; Gutteling, J.M.; Cadet, B. Perception of nuclear energy and coal in France and the Netherlands. Risk Anal. 1995, 15, 513-521. [CrossRef]

17. Greenberg, M.R.; Schneider, D.F. Gender differences in risk perception: Effects differ in stressed vs. non-stressed environments. Risk Anal. 1995, 15, 503-511. [CrossRef]

18. Sundström, A.; McCright, A.M. Women and nuclear energy: Examining the gender divide in opposition to nuclear power among swedish citizens and politicians. Energy Res. Soc. Sci. 2016, 11, 29-39. [CrossRef]

19. Rothman, S.; Lichter, S.R. Elite ideology and risk perception in nuclear energy policy. Am. Political Sci. Rev. 1987, 81, 383-404. [CrossRef]

20. Slovic, P.; Layman, M.; Flynn, J.H. Risk perception, trust, and nuclear waste: Lessons from Yucca Mountain. Environ. Sci. Policy Sustain. Dev. 1991, 33, 6-30. [CrossRef]

21. Chung, J.B.; Kim, H.-K. Competition, economic benefits, trust, and risk perception in siting a potentially hazardous facility. Landsc. Urban. Plan. 2009, 91, 8-16. [CrossRef]

22. Labarrere, C.A.; Woods, J.R.; Hardin, J.W.; Campana, G.L.; Ortiz, M.A.; Jaeger, B.R.; Wozniak, T.C. Early prediction of cardiac allograft vasculopathy and heart transplant failure. Am. J. Transplant. 2011, 11, 528-535. [CrossRef]

23. Goodfellow, M.J.; Williams, H.R.; Azapagic, A. Nuclear renaissance, public perception and design criteria: An exploratory review. Energy Policy 2011, 39, 6199-6210. [CrossRef]

24. Costa-Font, J.; Rudisill, C.; Mossialos, E. Attitudes as an expression of knowledge and "political anchoring": The case of nuclear power in the United Kingdom. Risk Anal. Int. J. 2008, 28, 1273-1288. [CrossRef]

25. Cale, T.; Kromer, M. Does proximity matter? Plant location, public awareness, and support for nuclear energy. Soc. Sci. J. 2015, 52, 148-155. [CrossRef]

26. Sun, C.; Zhu, X. Evaluating the public perceptions of nuclear power in China: Evidence from a contingent valuation survey. Energy Policy 2014, 69, 397-405. [CrossRef]

27. de Groot, J.I.M.; Steg, L.; Poortinga, W. Values, perceived risks and benefits, and acceptability of nuclear energy. Risk Anal. 2013, 33, 307-317. [CrossRef]

28. Kumiko, F.; Shaw, R. Preparing international joint project: Use of japanese flood hazard map in bangladesh. Int. J. Disaster Risk Manag. 2019, 1, 62-80.

29. Mano, R.; Kirshcenbaum, A.; Rapaport, C. Earthquake preparedness: A social media fit perspective to accessing and disseminating earthquake information. Int. J. Disaster Risk Manag. 2019, 1, 19-31. [CrossRef]

30. Vibhas, S.; Adu, G.B.; Ruiyi, Z.; Anwaar, M.A.; Rajib, S. Understanding the barriers restraining effective operation of flood early warning systems. Int. J. Disaster Risk Manag. 2019, 1, 1-17.

31. Cvetković, V.; Martinović, J. Inovative solutions for flood risk management. Int. J. Disaster Risk Manag. 2020, 2, 71-100. [CrossRef]

32. Huang, L.; Zhou, Y.; Han, Y.; Hammitt, J.K.; Bi, J.; Liu, Y. Effect of the Fukushima nuclear accident on the risk perception of residents near a nuclear power plant in China. Proc. Natl. Acad. Sci. USA 2013, 110, 19742-19747. [CrossRef]

33. Siegrist, M.; Cvetkovich, G. Perception of hazards: The role of social trust and knowledge. Risk Anal. 2000, 20, 713-720. [CrossRef]

34. Jun, E.; Kim, W.J.; Jeong, Y.H.; Chang, S.H.J.E.P. Measuring the social value of nuclear energy using contingent valuation methodology. Energy Policy 2010, 38, 1470-1476. [CrossRef]

35. Lyamzina, Y.; Slovic, P. Community-oriented risk communication in recovery efforts after radiological contamination/accidents. Risk Hazards Crisis Public Policy 2019, 10, 197-211. [CrossRef]

36. Frewer, L.J.; Scholderer, J.; Bredahl, L. Communicating about the risks and benefits of genetically modified foods: The mediating role of trust. J. Risk Anal. Int. J. 2003, 23, 1117-1133. [CrossRef] [PubMed]

37. Greenberg, M.; Lowrie, K.; Burger, J.; Powers, C.; Gochfeld, M.; Mayer, H. Nuclear waste and public worries: Public perceptions of the United States' major nuclear weapons legacy sites. Hum. Ecol. Rev. 2007, 14, 1-12.

38. Metlay, D. Institutional trust and confidence: A journey into a conceptual quagmire. Soc. Trust Manag. Risk 1999, 100-116. Available online: https://www.taylorfrancis.com/chapters/edit/10.4324/9781315071350-16/institutional-trust-confidencejourney-conceptual-quagmire-daniel-metlay (accessed on 22 April 2021).

39. Siegrist, M.; Cvetkovich, G.; Roth, C. Salient value similarity, social trust, and risk/benefit perception. Risk Anal. 2000, 20 , 353-362. [CrossRef] 
40. Viklund, M.J. Trust and risk perception in western Europe: A cross-national study. Risk Anal. Int. J. 2003, 23, 727-738. [CrossRef]

41. Malešič, M.; Prezelj, I.; Juvan, J.; Polič, M.; Uhan, S. Evacuation in the event of a nuclear disaster: Planned activity or improvisation? Int. J. Disaster Risk Reduct. 2015, 12, 102-111. [CrossRef]

42. Bell, W.C.; Dallas, C.E. Vulnerability of populations and the urban health care systems to nuclear weapon attack-examples from four American cities. Int. J. Health Geogr. 2007, 6, 5. [CrossRef]

43. Hellman, M. Risk analysis of nuclear deterrence. Bent Tau Beta Pi 2008, 99, 14-22.

44. Mortelmans, L.J.; Van Boxstael, S.; De Cauwer, H.G.; Sabbe, M.B. Preparedness of Belgian civil hospitals for chemical, biological, radiation, and nuclear incidents: Are we there yet? Eur. J. Emerg. Med. 2014, 21, 296-300. [CrossRef]

45. Zähringer, M.; Gering, F. Nuclear emergency preparedness in Germany: Lessons learned from fukushima and chernobyl and their implementation. In Nuclear Emergencies; Springer: Berlin/Heidelberg, Germany, 2019; pp. 229-236.

46. Hasegawa, M.; Murakami, M.; Takebayashi, Y.; Suzuki, S.; Ohto, H. Social capital enhanced disaster preparedness and health consultations after the 2011 Great East Japan Earthquake and nuclear power station accident. Int. J. Environ. Res. Public Health 2018, 15, 516. [CrossRef]

47. Razak, S.; Hignett, S.; Barnes, J. Emergency department response to chemical, biological, radiological, nuclear, and explosive events: A systematic review. Prehospital Disaster Med. 2018, 33, 543-549. [CrossRef]

48. Shah, N.A.; Shahzad, N.; Afzal, M.S. Nuclear disaster preparedness level of medical responders in pakistan. J. Nucl. Med. Technol. 2020, 49, 95-101. [CrossRef]

49. Kim, Y.; Kim, M.; Kim, W. Effect of the Fukushima nuclear disaster on global public acceptance of nuclear energy. Energy Policy 2013, 61, 822-828. [CrossRef]

50. Brumfiel, G. Fukushima: Fallout of fear. Nat. News 2013, 493, 290. [CrossRef]

51. Groen, R.S.; Bae, J.Y.; Lim, K.J. Fear of the unknown: Ionizing radiation exposure during pregnancy. Am. J. Obstet. Gynecol. 2012, 206, 456-462. [CrossRef]

52. Nishikawa, M.; Kato, T.; Homma, T.; Takahara, S. Changes in risk perceptions before and after nuclear accidents: Evidence from Japan. J. Environ. Sci. Policy 2016, 55, 11-19. [CrossRef]

53. Coval, J.D.; Moskowitz, T. Home bias at home: Local equity preference in domestic portfolios. J. Financ. 1999, 54, $2045-2073$. [CrossRef]

54. Garmaise, M.J.; Moskowitz, T.J. Adverse selection and re-trade. In The Center for Research in Security Prices; Working Paper; University of Chicago: Chicago, IL, USA, 1999.

55. Grinblatt, M.; Keloharju, M. How distance, language, and culture influence stockholdings and trades. J. Financ. 2001, 56, 1053-1073. [CrossRef]

56. Richardson, P.; Rickwood, K.; Rickwood, P. Public involvement as a tool to enhance nuclear safety. Energy Strategy Rev. 2013, 1, 266-271. [CrossRef]

57. Arikawa, H.; Cao, Y.; Matsumoto, S. Attitudes toward nuclear power and energy-saving behavior among Japanese households. Energy Res. Soc. Sci. 2014, 2, 12-20. [CrossRef]

58. World Energy Council. World Energy Perspective: Nuclear Energy One Year after Fukushima; World Energy Council: London, UK, 2012. Available online: https://www.worldenergy.org/assets/downloads/PUB_world_energy_perspective_nuclear_energy_ one_year_after_fukushima_2012_WEC.pdf (accessed on 24 March 2021).

59. WIN-Gallup International. Global Snap Poll on Tsunami in Japan and Impact on Views about Nuclear Energy. 2011. Available online: https:/ / www.redcresearch.ie/wp-content/uploads /2015/10/RED-C-Research-Press-Release-Japan-Earthquake-Survey_Snap-Poll_.pdf (accessed on 24 March 2021).

60. Kessides, I.N. The future of the nuclear industry reconsidered: Risks, uncertainties, and continued promise. Energy Policy 2012, 48, 185-208. [CrossRef]

61. Frantál, B.; Malý, J.; Ouředníček, M.; Nemeškal, J. Distance matters. Assessing socioeconomic impacts of the Dukovany nuclear power plant in the Czech Republic: Local perceptions and statistical evidence. Morav. Geogr. Rep. 2016, 24, 2-13. [CrossRef]

62. Adamantiades, A.; Kessides, I. Nuclear power for sustainable development: Current status and future prospects. Energy Policy 2009, 37, 5149-5166. [CrossRef]

63. World Nuclear Association (WNA). World Nuclear Performance Report. 2019. Available online: https: / /www.world-nuclear. org/our-association/publications/online-reports/world-nuclear-performance-report.aspx (accessed on 23 March 2021).

64. International Atomic Energy Agency (IAEA). Nuclear Power Reactors in the World; Reference Data Series No. 2; IAEA: Vienna, Austria, 2020.

65. Ahearne, J.F. Prospects for nuclear energy. Energy Econ. 2011, 33, 572-580. [CrossRef]

66. Barnaby, F. The nuclear renaissance: Nuclear weapons proliferation and terrorism. Inst. Public Policy Res. 2009. Available online: https://www.ippr.org/publications/the-nuclear-renaissance-nuclear-weapons-proliferation-and-terrorism (accessed on 22 April 2021).

67. Cotton, D.; Miller, W.; Winter, J.; Bailey, I.; Sterling, S. Knowledge, agency and collective action as barriers to energy-saving behaviour. Local Environ. 2016, 21, 883-897. [CrossRef]

68. Joppke, C. Mobilizing against Nuclear Energy: A Comparison of Germany and the United States; University of California Press: Oakland, CA, USA, 1993. 
69. Richards, G.; Noble, B.; Belcher, K. Barriers to renewable energy development: A case study of large-scale wind energy in Saskatchewan, Canada. Energy Policy 2012, 42, 691-698. [CrossRef]

70. Ertör-Akyazı, P.; Adaman, F.; Özkaynak, B.; Zenginobuz, Ü. Citizens' preferences on nuclear and renewable energy sources: Evidence from Turkey. Energy Policy 2012, 47, 309-320. [CrossRef]

71. Sun, C.; Zhu, X.; Meng, X. Post-Fukushima public acceptance on resuming the nuclear power program in China. Renew. Sustain. Energy Rev. 2016, 62, 685-694. [CrossRef]

72. Edwards, J.; Othman, M.; Burn, S. A review of policy drivers and barriers for the use of anaerobic digestion in Europe, the United States and Australia. Renew. Sustain. Energy Rev. 2015, 52, 815-828. [CrossRef]

73. Hong, S.; Bradshaw, C.J.; Brook, B.W. Nuclear power can reduce emissions and maintain a strong economy: Rating Australia's optimal future electricity-generation mix by technologies and policies. Appl. Energy 2014, 136, 712-725. [CrossRef]

74. Sainati, T.; Locatelli, G.; Smith, N. Project financing in nuclear new build, why not? The legal and regulatory barriers. Energy Policy 2019, 129, 111-119. [CrossRef]

75. Jewell, J. Ready for nuclear energy? An assessment of capacities and motivations for launching new national nuclear power programs. Energy Policy 2011, 39, 1041-1055. [CrossRef]

76. Peters, E.; Slovic, P. The role of affect and worldviews as orienting dispositions in the perception and acceptance of nuclear power. J. Appl. Soc. Psychol. 1996, 26, 1427-1453. [CrossRef]

77. Sjoberg, L.; Drottz-Sjoberg, B.-M. Public risk perception of nuclear waste. Int. J. Risk Assess. 2009, 11, 248-280. [CrossRef]

78. Sjoberg, L. Risk perception, emotion and policy: The case of nuclear technology. Eur. Rev. 2003, 11, 109-128. [CrossRef]

79. Glaser, A. From Brokdorf to Fukushima: The long journey to nuclear phase-out. Bull. At. Sci. 2012, 68, 10-21. [CrossRef]

80. Slovic, P. The Feeling of Risk: New Perspectives on Risk Perception; Routledge: New York, NY, USA, 2010.

81. Hayashi, M.; Hughes, L. The Fukushima nuclear accident and its effect on global energy security. Energy Policy 2013, 59, $102-111$. [CrossRef]

82. Visschers, V.H.M.; Siegrist, M. How a nuclear power plant accident influences acceptance of nuclear power: Results of a longitudinal study before and after the Fukushima disaster. Risk Anal. Int. J. 2013, 33, 333-347. [CrossRef]

83. Poortinga, W.; Pidgeon, N.; Capstick, S.; Aoyagi, M. Public Attitudes to Nuclear Power and Climate change in Britain Two Years after the Fukushima Accident-Synthesis Report; UK Energy Research Centre (UKERC): London, UK, 2014. Available online: http:/ / www.ukerc.ac.uk/asset/65EE60EE-C581-48D7-8ADC6D3D1BA5CED5/ (accessed on 24 March 2021).

84. Statistical Yearbook of the Republic of Serbia. Demographic Yearbook. 2020. Available online: https://publikacije.stat.gov.rs/G2 020/Pdf/G20202053.pdf (accessed on 24 March 2021).

85. Cvetković, V.; Dragićević, S.; Petrović, M.; Mijaković, S.; Jakovljević, V.; Gačić, J. Knowledge and perception of secondary school students in Belgrade about earthquakes as natural disasters. Pol. J. Environ. Stud. 2015, 24, 1553-1561. [CrossRef]

86. Official Gazette Republic of Serbia. Law on the Prohibition of the Construction of Nuclear Power Plants in the Federal Republic of Yugoslavia, 12/1995. National Assembly: Belgrade, Serbia, 2005.

87. Official Gazette Republic of Serbia. Adoption of the Radiation Safety and Security Law; No. 95; National Assembly: Belgrade, Serbia, 2018.

88. Official Gazette Republic of Serbia. Adoption of the Radiation Safety and Security Law; No. 10; National Assembly: Belgrade, Serbia, 2019.

89. Siegrist, M.; Sütterlin, B.; Keller, C. Why have some people changed their attitudes toward nuclear power after the accident in Fukushima? Energy Policy 2014, 69, 356-363. [CrossRef]

90. Mulder, K. The dynamics of public opinion on nuclear power. Interpreting an experiment in The Netherlands. Technol. Forecast. Soc. Chang. 2012, 79, 1513-1524. [CrossRef]

91. Flynn, J.; Slovic, P.; Mertz, C.K. The Nevada initiative: A risk communication fiasco. Risk Anal. 1993, 13, 497-502. [CrossRef]

92. Berube, D.M.; Cummings, C.L.; Frith, J.H.; Binder, A.R.; Oldendick, R. Comparing nanoparticle risk perceptions to other known EHS risks. J. Nanoparticle Res. 2011, 13, 3089-3099. [CrossRef]

93. Drottz-Sjöberg, B.M. Perceptions of nuclear wastes across extreme time perspectives. Risk Hazards Crisis Public Policy 2010, 1, 231-253. [CrossRef]

94. Jacobs, L.; Worthley, R. A comparative study of risk appraisal: A new look at risk assessment in different countries. Environ. Monit. Assess. 1999, 59, 225-247. [CrossRef]

95. Mah, D.N.-Y.; Hills, P.; Tao, J. Risk perception, trust and public engagement in nuclear decision-making in Hong Kong. Energy Policy 2014, 73, 368-390. [CrossRef]

96. Slovic, P. Perception of risk. Science 1987, 236, 280-285. [CrossRef]

97. Ansolabehere, S.; Konisky, D.M. Public attitudes toward construction of new power plants. Public Opin. Q. 2009, 73, 566-577. [CrossRef]

98. Visschers, V.H.M.; Siegrist, M. Exploring the triangular relationship between trust, affect, and risk perception: A review of the literature. Risk Manag. 2008, 10, 156-167. [CrossRef]

99. Greenberg, M.R. NIMBY, CLAMP, and the location of new nuclear-related facilities: US national and 11 site-specific surveys. Risk Anal. Int. J. 2009, 29, 1242-1254. [CrossRef] [PubMed]

100. He, G.; Mol, A.P.J.; Zhang, L.; Lu, Y. Nuclear power in China after Fukushima: Understanding public knowledge, attitudes, and trust. J. Risk Res. 2014, 17, 435-451. [CrossRef] 
101. Kim, S.; Lee, J.E.; Kim, D. Searching for the next new energy in energy transition: Comparing the impacts of economic incentives on local acceptance of fossil fuels, renewable, and nuclear energies. Sustainability 2019, 11, 2037. [CrossRef]

102. Midden, C.J.H.; Verplanken, B. The stability of nuclear attitudes after Chernobyl. J. Environ. Psychol. 1990, 10, 111-119. [CrossRef]

103. Tsujikawa, N.; Tsuchida, S.; Shiotani, T. Changes in the factors influencing public acceptance of nuclear power generation in Japan since the 2011 Fukushima Daiichi nuclear disaster. Risk Anal. 2016, 36, 98-113. [CrossRef]

104. De Groot, J.I.M.; Schweiger, E.; Schubert, I. Social influence, risk and benefit perceptions, and the acceptability of risky energy technologies: An explanatory model of nuclear power versus shale gas. Risk Anal. 2020, 40, 1226-1243. [CrossRef]

105. Huang, L.; He, R.; Yang, Q.; Chen, J.; Zhou, Y.; Hammitt, J.K.; Liu, Y. The changing risk perception towards nuclear power in China after the Fukushima nuclear accident in Japan. Energy Policy 2018, 120, 294-301. [CrossRef]

106. Solomon, L.S.; Tomaskovic-Devey, D.; Risman, B.J. The gender gap and nuclear power: Attitudes in a politicized environment. Sex Roles 1989, 21, 401-414. [CrossRef]

107. Cvetković, V.M.; Nikolić, N.; Radovanović Nenadić, U.; Öcal, A.; Noji, E.K.; Zečević, M. Preparedness and preventive behaviors for a pandemic disaster caused by COVID-19 in Serbia. Int. J. Environ. Res. Public Health 2020, 17, 4124. [CrossRef]

108. Cvetković, V.M.; Öcal, A.; Ivanov, A. Young adults' fear of disasters: A case study of residents from Turkey, Serbia and Macedonia. Int. J. Disaster Risk Reduct. 2019, 35, 101095. [CrossRef]

109. Öcal, A.; Cvetković, V.M.; Baytiyeh, H.; Tedim, F.M.S.; Zečević, M. Public reactions to the disaster COVID-19: A comparative study in Italy, Lebanon, Portugal, and Serbia. Geomat. Nat. Hazards Risk 2020, 11, 1864-1885. [CrossRef]

110. Flynn, J.; Slovic, P.; Mertz, C.K. Gender, race, and perception of environmental health risks. Risk Anal. 1994, 14, 1101-1108. [CrossRef] 